\title{
DFT Study on the Mechanism of Escherichia coli Inorganic Pyrophosphatase
}

\author{
Ling Yang, Rong-Zhen Liao, Jian-Guo Yu,* and Ruo-Zhuang Liu \\ College of Chemistry, Beijing Normal University, Beijing 100875, P. R. China
}

Received: November 13, 2008; Revised Manuscript Received: March 13, 2009

\begin{abstract}
Escherichia coli inorganic pyrophosphatase (E-PPase) is a tetranuclear divalent metal dependent enzyme that catalyzes the reversible interconversion of pyrophosphate (PPi) and orthophosphate (Pi), with $\mathrm{Mg}^{2+}$ conferring the highest activity. In the present work, the reaction mechanism of E-PPase is investigated using the hybrid density functional theory (DFT) method B3LYP with a large model of the active site. Our calculated results shed further light on the detailed reaction mechanism. In particular, the important residue Asp67, either protonated or unprotonated, was taken into account in the present calculations. Our calculations indicated that a protonated Asp67 is crucial for the reverse reaction to take place; however, it is lost sight of in the forward reaction. The bridging hydroxide is shown to be capable of performing nucleophilic in-line attack on the substrate from its bridging position in the presence of four $\mathrm{Mg}^{2+}$ ions. During the catalysis, the roles of the four magnesium ions are suggested to provide a necessary conformation of the active site, facilitate the nucleophile formation and substrate orientation, and stabilize the trigonal bipyramid transition state, thereby lowering the barrier for the nucleophilic attack.
\end{abstract}

\section{Introduction}

Soluble inorganic pyrophosphatases (PPases, EC 3.6.1.1) are ubiquitous enzymes that catalyze the reverse hydrolysis/synthesis of pyrophosphate (PPi), as illustrated in Scheme $1,{ }^{1}$ requiring three or four divalent metal cations for catalysis. ${ }^{2-4}$ PPases play important roles in intermediary metabolism and cell growth ${ }^{5,6}$ and belong to the phosphorus-transfer enzymes that form one of the largest classes of enzymes in nature. ${ }^{7,8}$ PPases control the intracellular level of PPi during the energy metabolism, thus providing an essential driving force for the synthesis of biopolymers, such as proteins, RNA, and DNA. ${ }^{9,10}$

PPases comprise two families, with different sequence and structure. ${ }^{11-15}$ In the more common family I PPases, Y-PPase from Saccharomyces cerevisiae and E-PPase from Escherichia coli are best-studied, with $\mathrm{Mg}^{2+}$ ions conferring optimal activity. ${ }^{1-3,16}$ The X-ray crystal structure of E-PPase complexed with pyrophosphate in the presence of metal cofactor, $\mathrm{Mg}^{2+}$, and $\mathrm{F}^{-}$has been reported (Figure 1). ${ }^{17}$ The fluoride occupying the same location as the bridging nucleophile was used as an reversible inhibitor to obtain the high-resolution crystal structure of PPi bound to the enzyme active site. ${ }^{18,19}$ Therefore, this crystal structure provided an almost unprecedented view of the molecular interactions between the substrate and the active site immediately before the hydrolysis reaction. The active site contains four $\mathrm{Mg}^{2+}$ ions (termed as $\mathrm{Mg} 1-\mathrm{Mg} 4$ ), in which $\mathrm{Mg} 1$ and $\mathrm{Mg} 2$ are bridged by $\mathrm{F}^{-}$, Asp70, and PPi. $\mathrm{Mg} 1$ and $\mathrm{Mg} 2$ were assumed to lower the $\mathrm{p} K_{\mathrm{a}}$ of the bridging water molecule, thereby facilitating the formation of the nucleophile. ${ }^{4,20,21} \mathrm{Mg} 3$ and $\mathrm{Mg} 4$ bind to the moiety of PPi and are coordinated to several negatively charged residues: Mg3 to Asp97 and Asp102, while Mg4 to Glu31. Therefore, the four metal ions play an essential role in the precise orientation of the substrate. ${ }^{22}$ Nine water molecules complete the octahedral coordination of the four magnesium ions. In addition, two lysines (Lys29, Lys142) and an argine (Arg43) bind to the substrate through electrostatic interactions. ${ }^{20,23}$ A second shell residue, Asp67, was suggested

\footnotetext{
* Corresponding author. E-mail: jianguo_yu@bnu.edu.cn.
}

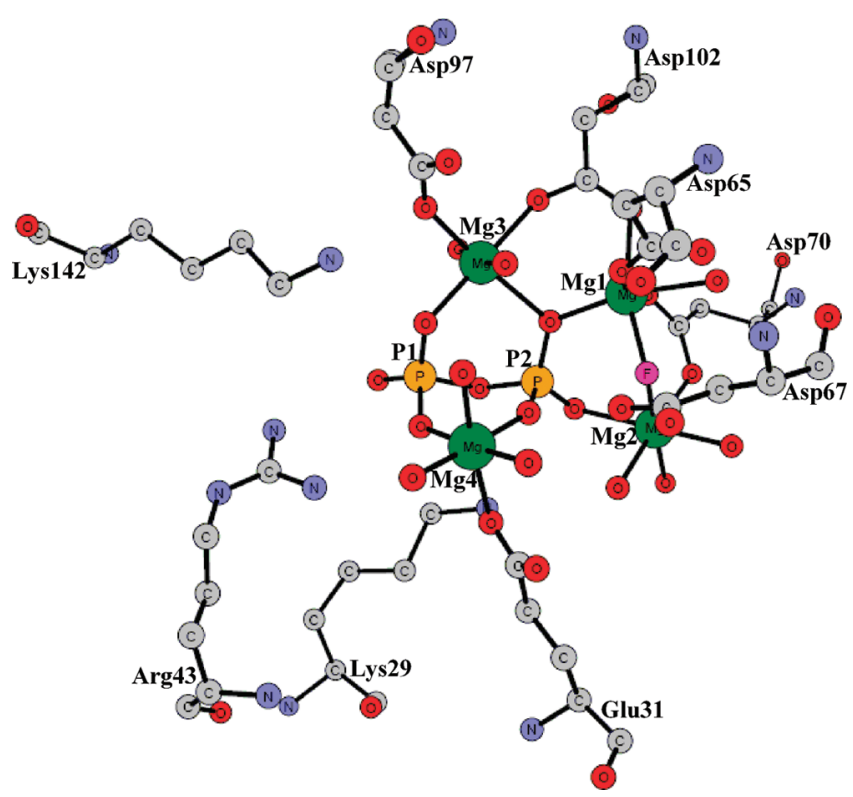

Figure 1. X-ray crystal structure of the active site of E-PPase in complex with substrate (PPi) and inhibitor fluoride.

SCHEME 1: Interconversion of PPi and Pi Catalyzed by E-PPase

$$
\mathrm{H}_{2} \mathrm{P}_{2} \mathrm{O}_{7}^{2-}+\mathrm{H}_{2} \mathrm{O} \stackrel{\text { E-PPase }}{\rightleftharpoons} 2 \mathrm{H}_{2} \mathrm{PO}_{4}^{-}
$$

to be directly involved in catalysis, acting as a general base to deprotonate the bridging water molecule. ${ }^{17,19,24} \mathrm{~A}$ similar role has been suggested for Glu204 in methionine aminopeptidase (MetAP), ${ }^{25 a}$ Glu270 in carboxypeptidase $A,{ }^{25 b}$ Asp120 in $\beta$-lactamase, ${ }^{25 c}$ Glu106 in carbonic anhydrase, ${ }^{25 d}$ and Glu133 in peptide deformylase. ${ }^{25}$ Kinetic measurements of mutant enzymes showed that mutation of the amino acid residues in the active site led to impaired catalytic activity or decreased substrate binding affinity. $8,20,24,26-29$ 
SCHEME 2: Suggested Mechanisms for the Catalytic Reaction of E-PPase

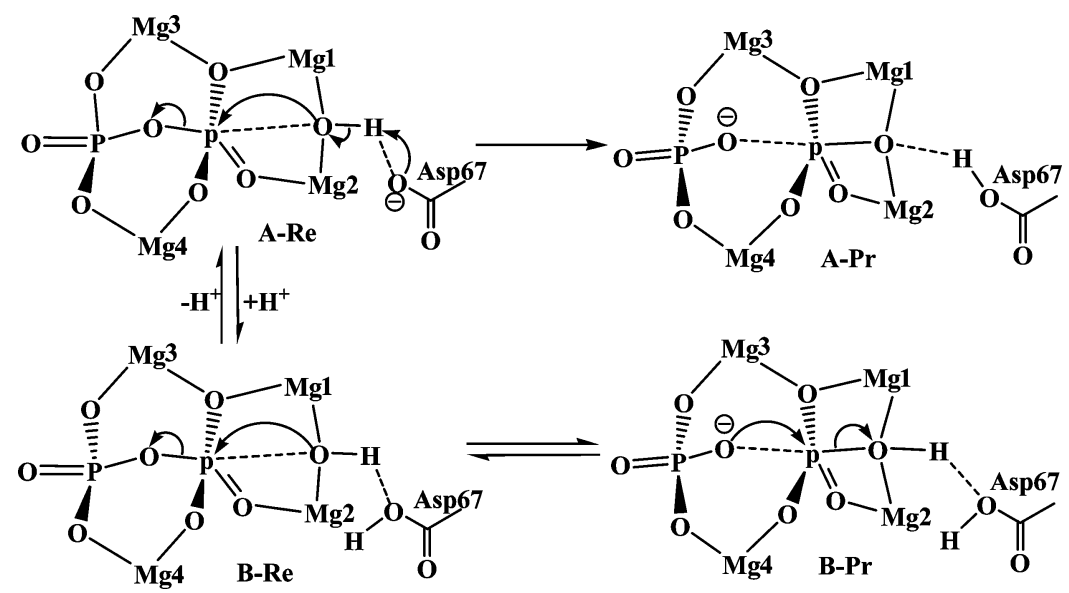

The reaction mechanism of the E-PPase has been put forward on the basis of a number of kinetic ${ }^{1,3,8,16 \mathrm{~d}, \mathrm{e}, 18,20,24,27-29}$ and structural $^{3,15,17,21,22,30}$ studies. Gonzalez et al. suggested that the hydrolysis reaction proceeds via direct phosphoryl transfer to water without formation of a phosphorylated enzyme intermediate. ${ }^{31}$ Later, Harutyunyan proposed the possible structure of the transition state. ${ }^{32}$ In addition, experimentalists deduced that a water molecule or a hydroxide performs the nucleophilic attack on the PPi, ${ }^{1,3,4,18-20,24}$ which was supported by analyzing the structure of R78K and D117E Y-PPase. ${ }^{28}$ Furthermore, the ${ }^{18} \mathrm{O}$ labeled experiment indicated that the hydrolysis of PPi is appreciably reversible. ${ }^{1}$ In spite of these instructive experimental studies on the reaction mechanism of E-PPase, there are still a lot of important mechanistic questions unsolved. For example, why are four magnesium ions indispensable for the reactivity, which is unique in nature? What is the bridging species, a water molecule or a hydroxide? How can the enzyme accelerate the reaction rate by $10^{10}$-fold?

In this paper, we have investigated the reaction mechanisms of E-PPase using the hybrid density functional theory (DFT) method B3LYP. ${ }^{33} \mathrm{We}$ constructed a model of the active site on the basis of the crystal structure (PDB ID 2auu) and calculated a potential-energy surface for the reaction. This approach has previously been successfully applied to the study of a number of enzyme mechanisms. ${ }^{25,34}$ In the comparison with E-PPase, mechanisms of the uncatalyzed reactions were also studied at the B3LYP calculating level and in aqueous solution.

\section{Computational Details}

The important active site residue Asp67 could be protonated or unprotonated in our considerations, so both possible mechanistic pathways were considered (shown in Scheme 2) in this study. All calculations were performed using the DFT functional B3LYP. ${ }^{33}$ For the enzyme-catalyzed reactions, geometry optimizations were carried out with the $6-31 \mathrm{G}(\mathrm{d}$, p) basis sets for $\mathrm{C}, \mathrm{N}, \mathrm{O}$, and $\mathrm{H}$ and the $6-311+\mathrm{G}(\mathrm{d})$ basis sets for $\mathrm{Mg}$ and $\mathrm{P}$ elements. On the basis of these optimized geometries, more accurate energies were obtained by performing single-point calculations with the larger basis set $6-311++\mathrm{G}(2 \mathrm{~d}, 2 \mathrm{p})$ for all elements. The dielectric effects from the protein surroundings that are not explicitly included in the model were calculated at the same theory level as the geometry optimizations using the conductor-like polarizable continuum model (CPCM) method ${ }^{35}$ with the standard dielectric constant of four $(\varepsilon=4)$. In the study for the hydrolysis of pyrophosphate dianion $\left(\mathrm{H}_{2} \mathrm{P}_{2} \mathrm{O}_{7}{ }^{2-}\right)$ and pyrophosphate trianion $\left(\mathrm{HP}_{2} \mathrm{O}_{7}{ }^{3-}\right)^{36}$ without catalyst, we adopted the B3LYP/6-311+G(d,p) level to optimize geometries in water using the CPCM method. Furthermore, the single-point calculations were performed at the B3LYP/6-311++G(2d,2p) level based on the optimized geometries in the solution phase.

Frequency calculations were performed at the same theory level as optimizations to obtain zero-point energies (ZPE) and to confirm the nature of various stationary points. The latter implies no negative eigenvalues for minima and only one negative eigenvalue for transition states for Hessian matrixes. As will be discussed below, some atoms were fixed to their $\mathrm{X}$-ray crystal positions during optimization. This procedure gives rise to a few small imaginary frequencies, typically on order of $10 \mathrm{i}-50 \mathrm{i} \mathrm{cm}^{-1}$. The number of imaginary frequencies in the unprotonated model, excluding that for the reaction coordinate, is two more in both the reactant $\left(15 \mathrm{i}\right.$ and $\left.6 \mathrm{i} \mathrm{cm}^{-1}\right)$ and the transition state $\left(14 \mathrm{i}\right.$ and $\left.9 \mathrm{i} \mathrm{cm}{ }^{-1}\right)$ than that in product. While for the protonated model, the number becomes one more in product $\left(18 \mathrm{i} \mathrm{cm}^{-1}\right)$ than that for reactant and transition state. These imaginary frequencies attributed to the geometric parameters related directly to the fixed atoms do not significantly contribute to the ZPE and can thus be tolerated. The energies reported herein are corrected for both solvation and zero-point vibrational effects. All calculations were performed using the Gaussian 03 program package. ${ }^{37}$

\section{Model of Active Site}

On the basis of the high-resolution crystal structure (PDB code 2 auu $)^{17}$ (see Figure 1), we devised two models of the active site of E-PPase complexed with PPi, in which the important residue Asp67 is either unprotonated (model A) or protonated (model B). Both the models contain the four magnesium ions as well as their first shell ligands, including a bridging hydroxide, which appeared in the position of the fluoride at the X-ray structure; four aspartates (Asp65, Asp70, Asp97, Asp102); a glutamate (Glu31); and nine water molecules. In addition, four important second-shell residues, Lys29, Lys142, Arg43, and Asp67, were also included in the models. The selected residues were truncated so that in principle only the side chains were kept in the models. Thus, the aspartates and the glutamate were modeled by acetates, the lysines by ethylamines, and the arginine by an $N$-methylguanidine. The total charge of model A and model $\mathrm{B}$ is 0 and +1 , respectively. To keep the optimized structures close to those obtained experimentally, the truncation atoms were fixed to their corresponding positions from the X-ray structure. The fixed atoms are marked with asterisks in Figures $2-4$. 

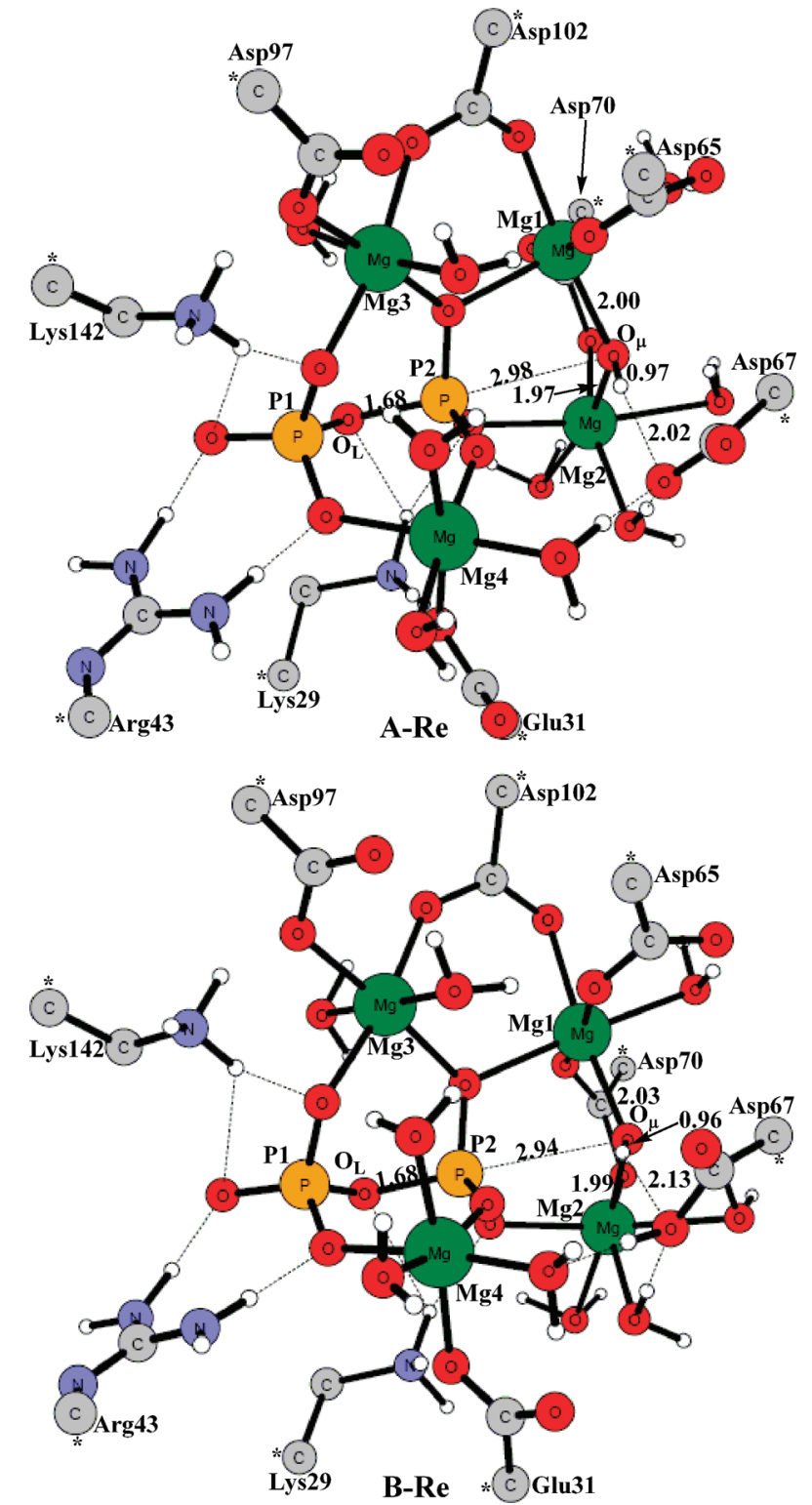

Figure 2. Optimized structures for the reactant with Asp67 unprotonated (A-Re) and prontonated (B-Re). Atoms marked with asterisks were fixed at their X-ray structure positions. For clarity, unimportant hydrogen atoms are omitted. The bond distances are in angstroms.

\section{Results and Discussion}

The calculating studies for carboxypeptidase A by Russo's group $^{25 \mathrm{~b}}$ elucidated that the barrierless process is the shift of a proton from the zinc-bound water to the formate anion representing Glu270. Because shifting a proton from the magnesium-bound water to the anionic Asp67 is a similar process, we referenced their computation strategies in the study for E-PPase.

As mentioned above, the protonation state of Asp67 is not well established. Therefore, we consider both possibilities (Scheme 2). The optimized structures of the E-PPase activesite model in complex with PPi with different protonation states of Asp67 (called as A-Re and B-Re) are shown in Figure 2. The overall geometric parameters obtained from optimizations are in good agreement with the experimental structure. For example, the four magnesium ions are all octahedrally coordinated in both models, the same as in the X-ray structure. In addition, the calculated distances between pairs of the four magnesium centers in models $\mathrm{A}$ and $\mathrm{B}$ are also comparable to the crystallographic distances (see Table 1).

We note that in A-Re Asp67 forms hydrogen bonds to the bridging hydroxide and to the two water molecules coordinated to $\mathrm{Mg} 2$ and $\mathrm{Mg} 4$. However, one hydrogen-bonding mode is changed in $\mathrm{B}-\mathrm{Re}$, in which the $\mathrm{OH}$ group in Asp67 donates a hydrogen bond to the water molecule coordinated to $\mathrm{Mg} 4$. In addition, the hydrogen-bond distance between Asp67 and $\mathrm{O}_{\mu} \mathrm{H}^{-}$ is $2.13 \AA$, which is longer than that in A-Re (2.02 $\AA$ ). In both $\mathrm{A}-\mathrm{Re}$ and $\mathrm{B}-\mathrm{Re}$, there is a nearly straight line between $\mathrm{O}_{\mu}, \mathrm{P} 2$, and $\mathrm{O}_{\mathrm{L}}$, with the corresponding angle being $172.2^{\circ}$ and $172.3^{\circ}$ for A-Re and B-Re, respectively. This attacking mode is similar to that of the nonenzymatic hydrolysis of paraoxon. ${ }^{38}$ All four magnesium ions play an important role in substrate orientation, facilitating the nucleophilic attack by the bridging hydroxide. The fact that the bridging ligand of the metal ions is a hydroxide appears to be a common theme, as similar proposals were demonstrated for several dizinc enzymes, such as phosphotriesterase (PTE), ${ }^{34,39}$ MetAP, ${ }^{25 a}$ aminopeptidase from Aeromonas proteolytica (AAP), ${ }^{34 \mathrm{~g}}$ dihydroorotase (DHO), ${ }^{34 \mathrm{~h}} \mathrm{~N}$-acyl-Lhomoserine lactone hydrolase (AHL lactonase), ${ }^{34 \mathrm{i}}$ and glyoxalase II (GlxII). ${ }^{34 \mathrm{j}}$

Hydrolysis through Model A. Starting from A-Re, we have optimized the structure of the transition state for the nucleophilic attack (A-TS) and the resulting product (A-Pr) for model A (shown in Figure 3). The barrier is calculated to be a very feasible $9.1 \mathrm{kcal} \mathrm{mol}^{-1}\left(8.2 \mathrm{kcal} \mathrm{mol}^{-1}\right.$ without the solvation correction) and A-Pr is found to lie $10.6 \mathrm{kcal} \mathrm{mol}^{-1}(14.8 \mathrm{kcal}$ $\mathrm{mol}^{-1}$ without the solvation correction) lower than A-Re (shown in Figure 5). We find that the nucleophilic attack occurs directly from the bridging position, similarly to other dizinc-dependent phosphorus transfer enzymes, namely phosphotriesterase. ${ }^{34,39}$ A-TS is characterized by an imaginary frequency of $130 \mathrm{im}^{-1}$. The relative higher barrier for the reverse reaction and the large driving force indicate that the synthesis might be not easy to occur in this model.

In A-TS, the critical $\mathrm{O}_{\mu}-\mathrm{P} 2$ distance is $2.09 \AA$, which is dramatically decreased from $2.98 \AA$ in A-Re, and the $\mathrm{P} 2-\mathrm{O}_{\mathrm{L}}$ distance is elongated from 1.68 to $1.88 \AA$. The proton is still attached to the bridging oxygen with a distance of $0.98 \AA$. However, the hydrogen-bond distance between Asp67 and $\mathrm{O}_{\mu} \mathrm{H}^{-}$ decreases from $2.02 \AA$ in A-Re to $1.88 \AA$ in A-TS, which is important for the proton transfer after A-TS. Downhill from A-TS, a proton transfer was observed from $\mathrm{O}_{\mu} \mathrm{H}^{-}$to Asp67. In A-Pr, the $\mathrm{O}_{\mu}-\mathrm{P} 2$ and $\mathrm{P} 2-\mathrm{O}_{\mathrm{L}}$ distances are 1.63 and $3.62 \AA$, respectively.

During the phosphorus transfer, a negative charge is transferred from the Asp67 in A-Re to a phosphate bond to Mg3 and Mg4 in A-Pr. We notice that three positively charged second shell residues, Arg43, Lys29, and Lys142, provide electrostatic stabilization to this emerged negative charge on the phosphate during the $\mathrm{P} 2-\mathrm{O}_{\mathrm{L}}$ cleavage. As seen in Table 2, the hydrogen bond distance between Lys29 and $\mathrm{O}_{\mathrm{L}}(\mathrm{r} 11)$ decreases from 2.43 $\AA$ in A-Re to $1.89 \AA$ in A-TS and further to $1.48 \AA$ in A-Pr. In addition, all four magnesium ions are involved in shielding the negative charge of PPi, thereby increasing the electrophilicity of the phosphorus center. The variation of $\mathrm{Mg}-\mathrm{Mg}$ distances (see Table 1) during the reaction indicates enough flexibility of the tetranuclear site, which might be helpful for the phosphorus transfer.

Hydrolysis through Model B. The calculated energetics in model A described above predicts an irreversible hydrolysis pathway. However, the experimental kinetic studies suggested a reversible interconversion of pyrophosphate and orthophos- 

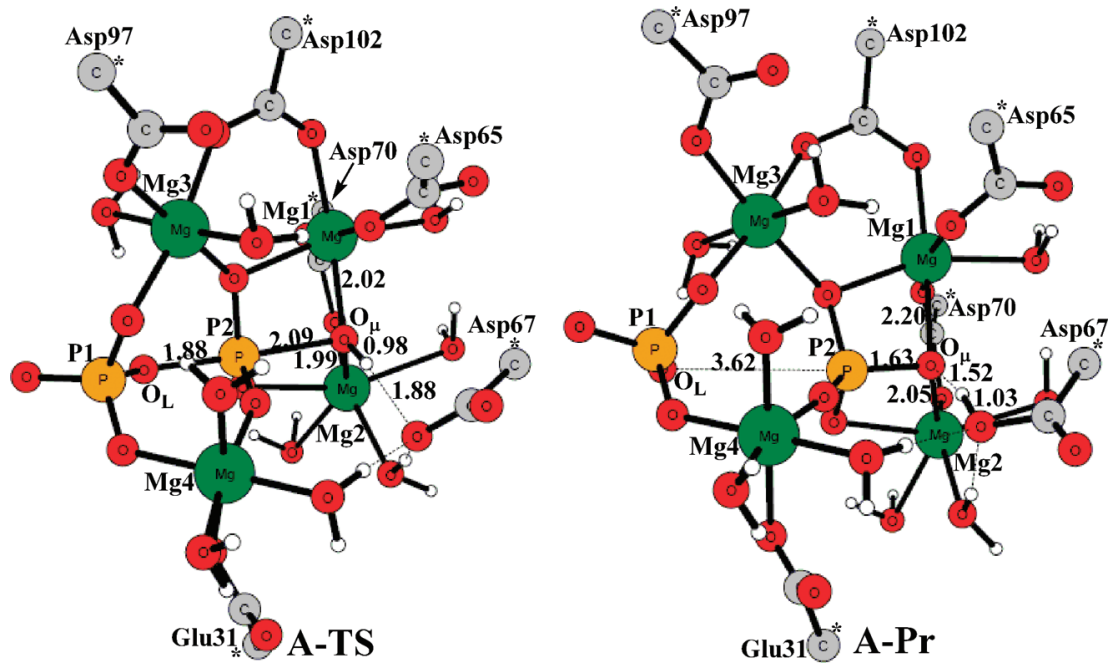

Figure 3. Optimized geometries of transition state (A-TS) and product (A-Pr) along the reaction pathway with Asp67 unprotonated (model A). For clarity, Arg43, Lys29, and Lys142 are omitted.
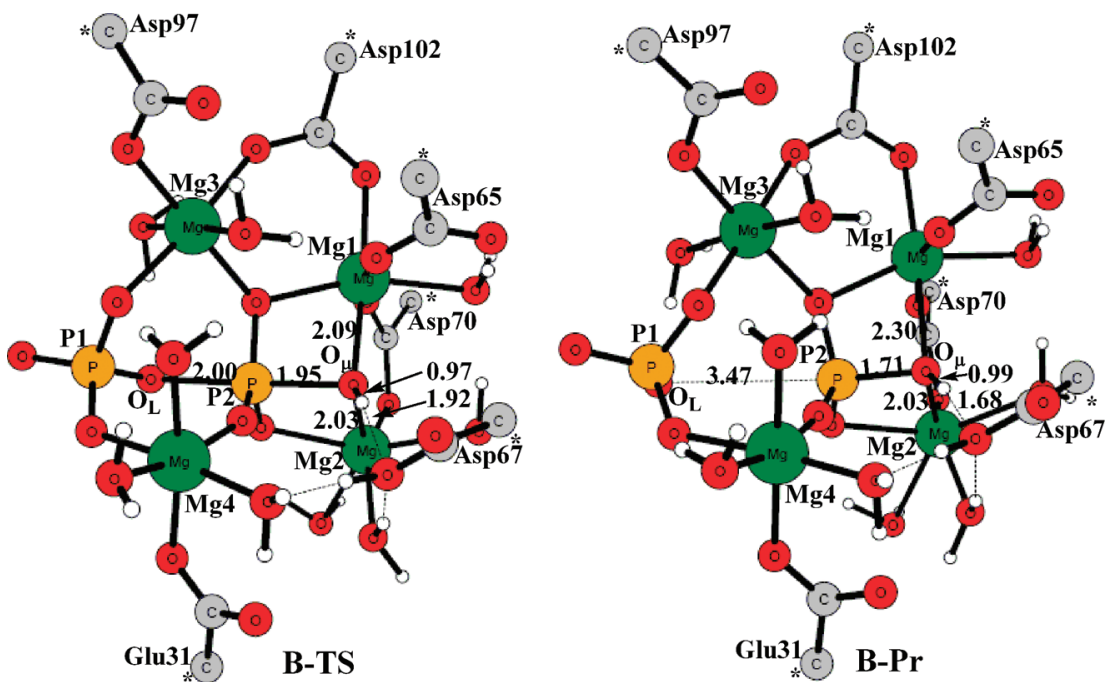

Figure 4. Optimized geometries of transition-state (B-TS) and product (B-Pr) along the reaction pathway with Asp67 protonated (model B).

TABLE 1: Distances $(\AA)$ between the Metal Ions in the Species Structures

\begin{tabular}{|c|c|c|c|c|c|c|c|c|}
\hline & \multicolumn{2}{|c|}{$R_{\mathrm{Mg} 1-\mathrm{Mg} 2}$} & \multicolumn{2}{|c|}{$R_{\mathrm{Mg} 1-\mathrm{Mg} 3}$} & \multicolumn{2}{|c|}{$R_{\mathrm{Mg} 2-\mathrm{Mg} 4}$} & \multicolumn{2}{|c|}{$R_{\mathrm{Mg} 3-\mathrm{Mg} 4}$} \\
\hline & model A & model B & model A & model B & model A & $\overline{\text { model } B}$ & model A & model $\mathrm{B}$ \\
\hline $\operatorname{Re}$ & 3.44 & 3.48 & 3.65 & 3.68 & 5.17 & 5.26 & 4.89 & 4.85 \\
\hline $\mathrm{Pr}$ & 3.55 & 3.62 & 3.57 & 3.63 & 5.51 & 5.62 & 4.78 & 4.81 \\
\hline $2 \mathrm{auu}^{a}$ & \multicolumn{2}{|c|}{3.48} & \multicolumn{2}{|c|}{3.62} & \multicolumn{2}{|c|}{5.38} & \multicolumn{2}{|c|}{4.85} \\
\hline
\end{tabular}

${ }^{a}$ 2auu is the X-ray structure.

phate. ${ }^{1}$ We therefore considered another model with a protonated Asp67, as the protonation state may change the energetics of the reaction. ${ }^{25}$

In B-Re, the $\mathrm{O}_{u}-\mathrm{P} 2$ distance is $2.94 \AA$, similar with that of A-Re $(2.98 \AA)$. The optimized transition state for nucleophilic attack (B-TS) and the resulting product (B-Pr) are displayed in Figure 4. The local structure of the transition state is similar to A-TS; the nucleophilic attack occurs from a bridging position and the $\mathrm{O}_{\mu}-\mathrm{P} 2$ and $\mathrm{P} 2-\mathrm{O}_{\mathrm{L}}$ distances at transition state are 1.95 and $2.00 \AA$ (2.09 and $1.88 \AA$ in A-TS), respectively. However, no proton transfer from the bridging hydroxide group to Asp67 occurs after B-TS, as Asp67 is already protonated. Therefore, a negative charge is transferred from the bridging hydroxide to $\mathrm{O}_{\mathrm{L}}$, which is different from that in model $\mathrm{A}$ as discussed above.
In addition, the barriers for the forward reaction are calculated to be $9.4 \mathrm{kcal} \mathrm{mol}^{-1}\left(9.1 \mathrm{kcal} \mathrm{mol}^{-1}\right.$ without the solvation correction), quite close to that in model A $\left(9.1 \mathrm{kcal} \mathrm{mol}^{-1}\right)$, and it is $11.5 \mathrm{kcal} \mathrm{mol}^{-1}\left(13.5 \mathrm{kcal} \mathrm{mol}^{-1}\right.$ without the solvation correction) for the backward reaction, dramatically decreased from $19.7 \mathrm{kcal} \mathrm{mol}^{-1}$ in model $\mathrm{A}$. The fact that the hydrolysis is faster is consistent with experimental kinetic studies, in which the hydrolysis/synthesis rates of PPi are 1030 and $222 \mathrm{~s}^{-1}$, respectively. ${ }^{1}$ In addition, the reaction energy of $2.1 \mathrm{kcal} \mathrm{mol}^{-1}$ in this model also agrees with the reaction energy of PPi hydrolysis in $\mathrm{MgCl}_{2}$ solution. ${ }^{40}$ Our calculations suggest a reversible pathway when Asp67 is protonated, which might be due to the different proton affinity of A-Re and A-Pr. Compared with model A, the protonation of Asp67, which depends on its 


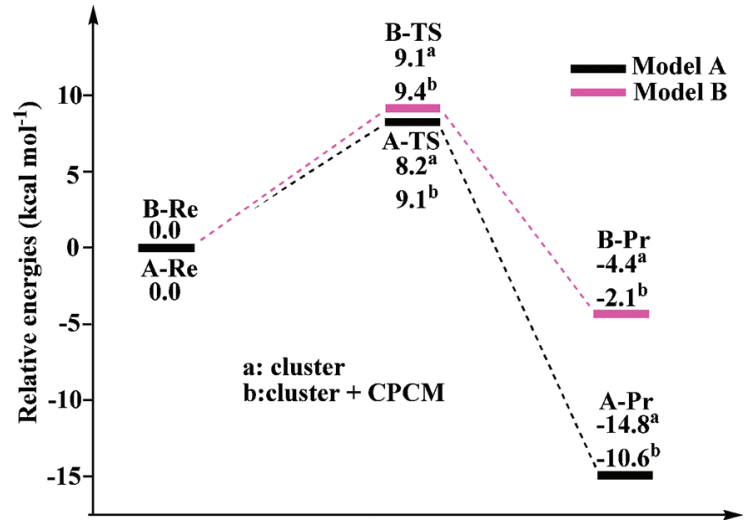

Figure 5. Potential energy profiles for the hydrolysis of PPi by E-PPase in two different models with Asp67 unprotonated (model A) and protonated (model B).

TABLE 2: Important Distances $(\AA)$ for the Various Stationary Points along the Reaction Pathways

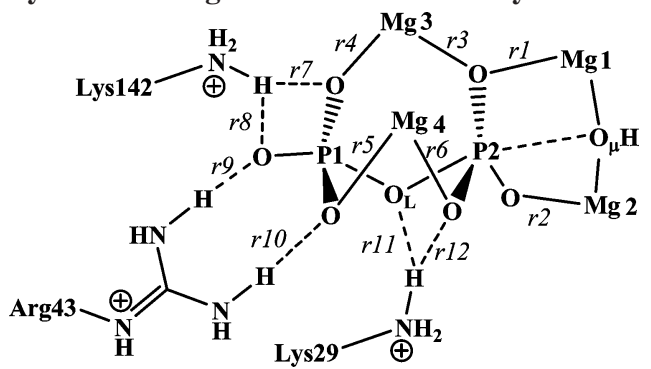

\begin{tabular}{lcccccc}
\hline & A-Re & B-Re & A-TS & B-TS & A-Pr & B-Pr \\
\hline r1 & 2.23 & 2.24 & 2.13 & 2.12 & 2.10 & 2.15 \\
r2 & 2.08 & 2.04 & 2.11 & 2.07 & 2.11 & 2.13 \\
r3 & 2.13 & 2.15 & 2.09 & 2.11 & 2.12 & 2.20 \\
r4 & 2.16 & 2.18 & 2.15 & 2.16 & 2.06 & 2.07 \\
r5 & 2.10 & 2.06 & 2.08 & 2.04 & 2.05 & 2.09 \\
r6 & 1.99 & 1.98 & 1.97 & 1.96 & 1.97 & 1.97 \\
r7 & 1.59 & 1.65 & 1.53 & 1.60 & 2.43 & 2.52 \\
r8 & 2.69 & 2.68 & 2.69 & 2.63 & 1.55 & 1.60 \\
r9 & 1.53 & 1.56 & 1.49 & 1.52 & 1.47 & 1.52 \\
r10 & 1.62 & 1.69 & 1.62 & 1.70 & 1.59 & 1.73 \\
r11 & 2.43 & 2.42 & 1.89 & 1.67 & 1.48 & 1.43 \\
r12 & 1.89 & 1.84 & 2.14 & 2.78 & 3.00 & 3.13
\end{tabular}

local $\mathrm{p} K_{\mathrm{a}}$ in the active site and the $\mathrm{pH}$ environment of the solution, is crucial for the synthesis of PPi.

To test the high catalytic efficiency of E-PPase, we also investigated the mechanism for the uncatalyzed reaction in aqueous solution (see Figure 6). For the forward step, the calculated energy barriers, $34.7 \mathrm{kcal} \mathrm{mol}^{-1}$ for $\mathrm{H}_{2} \mathrm{P}_{2} \mathrm{O}_{7}{ }^{2-}$ and $53.8 \mathrm{kcal} \mathrm{mol}^{-1}$ for $\mathrm{HP}_{2} \mathrm{O}_{7}{ }^{3-}$, are higher than those of catalyzed reaction model A by $25.6 / 44.7 \mathrm{kcal} \mathrm{mol}^{-1}$ and model B by $25.3 /$ $44.4 \mathrm{kcal} \mathrm{mol}^{-1}$. Similar cases for the reverse reactions were observed. These results demonstrated that E-PPase is very efficient for both directions of the reaction.

\section{Conclusions}

In this paper, we have investigated the reaction mechanism of the reversible interconversion of pyrophosphate and orthophosphate by E-PPase. Two possible mechanisms based on the prontonation state of Asp67 were considered (see Scheme 2). The energies obtained are presented in Figure 5 and important optimized geometric parameters of the stationary points are summarized in Tables 1 and 2.

Our calculations show that the protonation state of Asp67 governs the reversibility of the reaction. A protonated Asp67

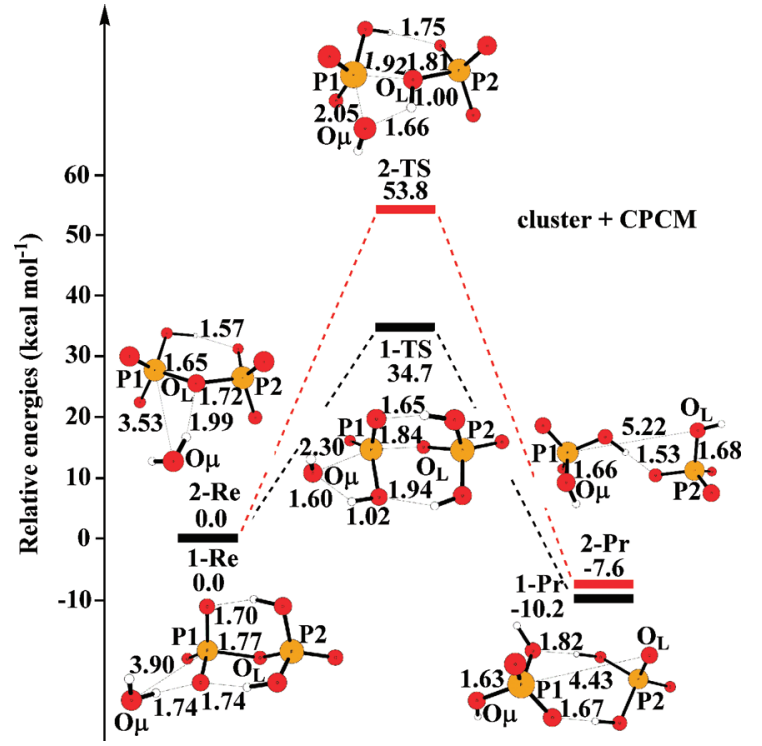

Figure 6. Potential energy profiles for the uncatalyzed reactions $\left(\mathrm{H}_{2} \mathrm{P}_{2} \mathrm{O}_{7}{ }^{2-}+\mathrm{H}_{2} \mathrm{O}(1-\mathrm{Re}) \rightarrow 1-\mathrm{TS} \rightarrow 2 \mathrm{H}_{2} \mathrm{PO}_{4}^{-}\right.$(1-Pr) in black and $\mathrm{HP}_{2} \mathrm{O}_{7}{ }^{3-}+\mathrm{H}_{2} \mathrm{O}(2-\mathrm{Re}) \rightarrow 2-\mathrm{TS} \rightarrow \mathrm{H}_{2} \mathrm{PO}_{4}{ }^{-}+\mathrm{HPO}_{4}{ }^{2-}$ (2-Pr) in red) in aqueous solution.

is indispensable for the synthesis of PPi. The substrate binds to the active site through direct coordination to four magnesium ions and hydrogen binding to three positively charged residues, Arg43, Lys29, and Lys142. All these interactions help shield the negative charge of PPi and increase the electrophility of the phosphorus center. $\mathrm{Mg} 1$ and $\mathrm{Mg} 2$ lowers the $\mathrm{p} K_{\mathrm{a}}$ of the bridging water molecule, facilitating the generation of a bridging hydroxide, which then acts as a nucleophile, attacking the phosphorus of the substrate. All four magnesium ions are involved in stabilizing the trigonal bipyramid transition state, thereby lowering the barrier for the nucleophilic attack.

When Asp67 is protonated, the reaction is calculated to be almost thermoneutral $\left(-2.1 \mathrm{kcal} \mathrm{mol}^{-1}\right)$. The energetic barrier for the forward reaction is calculated to be $9.4 \mathrm{kcal} \mathrm{mol}^{-1}$, whereas that for the reverse reaction is $11.5 \mathrm{kcal} \mathrm{mol}^{-1}$.

Acknowledgment. We appreciate Dr. Sven de Marothy (from Stockholm University) for providing xyzviewer to create all the figures of the molecule models. This work was supported by grants from the National Natural Science Foundation of China (Grant Nos. 20573011, 20733002, and 20873008) and Major State Basic Research Development Programs (Grant Nos. 2004CB719903 and 2002CB613406).

Supporting Information Available: Cartesian coordinates of all optimized structures. This material is available free of charge via the Internet at http://pubs.acs.org.

\section{References and Notes}

(1) Baykov, A. A.; Shestakov, A. S.; Kasho, V. N.; Vener, A. V.; Ivanov, A. H. Eur. J. Biochem. 1990, 194, 879-887.

(2) Cooperman, B. S. Methods Enzymol. 1982, 87, 526-548.

(3) Cooperman, B. S.; Baykov, A. A.; Lahti, R. Trends Biochem. Sci. 1992, 17, 262-266.

(4) Baykov, A. A.; Hyytia, T.; S.; Volk, E.; Kasho, V. N.; Vener, A. V.; Goldman, A.; Lahti, R.; Cooperman, B. S. Biochemistry 1996, 35, 46554661.

(5) Chen, J.; Brevet, A.; Fromant, M.; Lévêque, F.; Schmitter, J.-M.; Blanquet, S.; Plateau, P. J. Bacteriol. 1990, 172, 5686-5689.

(6) Lundin, M.; Baltscheffsky, H.; Ronne, H. J. Biol. Chem. 1991, 266, 12168-12172.

(7) Knowles, J. R. Аnпи. Rev. Biochem. 1980, 49, 877-919. 
(8) Käpylä, J.; Hyytiä, T.; Lahti, R.; Goldman, A.; Baykov, A. A.; Cooperman, B. S. Biochemistry 1995, 34, 792-800.

(9) Kornberg, A. In Horizons in Biochemistry; Kasha, H., Pullman,

B., Eds.; Academic Press: New York, 1962; pp 251-264.

(10) Peller, L. Biochemistry 1976, 15, 141-146.

(11) Shintani, T.; Uchiumi, T.; Yonezawa, T.; Salminen, A.; Baykov, A. A.; Lahti, R.; Hachimori, A. FEBS Lett. 1998, 439, 263-266.

(12) Young, T. W.; Kuhn, N. J.; Wadeson, A.; Ward, S.; Burges, D.; Cooke, G. D. Microbiology 1998, 144, 2563-2571.

(13) Merckel, M. C.; Fabrichniy, I. P.; Salminen, A.; Kalkkinen, N.; Baykov, A. A.; Lahti, R.; Goldman, A. Structure 2001, 9, 289-297.

(14) Ahn, S.; Milner, A. J.; Fütterer, K.; Konopka, M.; Ilias, M.; Young, T. W.; White, S. A. J. Mol. Biol. 2001, 313, 797-811.

(15) Fabrichniy, I. P.; Lehtiö, L.; Tammenkoski, M.; Zyryanov, A. B.; Oksanen, E.; Baykov, A. A.; Lahti, R.; Goldman, A. J. Biol. Chem. 2007, $282,1422-1431$.

(16) (a) Kunitz, M. J. Gen. Physiol. 1952, 35, 423-450. (b) Baykov, A. A.; Avaeva, S. M. Eur. J. Biochem. 1973, 32, 136-142. (c) Welsh, K. M.; Jacobyansky, A.; Springs, B.; Cooperman, B. S. Biochemistry 1983, 22 2243-2248. (d) Baykov, A. A.; Shestakov, A. S. Eur. J. Biochem. 1992, 206, 463-470. (e) Belogurov, G. A.; Fabrichniy, I. P.; Pohjanjoki, P.; Kasho, V. N.; Lehtihuhta, E.; Turkina, M. V.; Cooperman, B. S.; Goldman, A.; Baykov, A. A.; Lahti, R. Biochemistry 2000, 39, 13931-13938.

17) Samygina, V. R.; Moiseev, V. M.; Rodina, E. V.; Vorobyeva, N. N.; Popov, A. N.; Kurilova, S. A.; Nazarova, T. I.; Avaeva, S. M.; Bartunik, H. D. J. Mol. Biol. 2007, 366, 1305-1317.

(18) Pohjanjoki, P.; Fabrichniy, I. P.; Kasho, V. N.; Cooperman, B. S.; Goldman, A.; Baykov, A. A.; Lahti, R. J. Biol. Chem. 2001, 276, 434441.

(19) Heikinheimo, P.; Tuominen, V.; Ahonen, A.-K.; Teplyakov, A.; Cooperman, B. S.; Baykov, A. A.; Lahti, R.; Goldman, A. Proc. Natl. Acad. Sci. U.S.A. 2001, 98, 3121-3126.

(20) Salminen, T.; Käpylä, J.; Heikinheimo, P.; Kankare, J.; Goldman, A.; Heinonen, J.; Baykov, A. A.; Cooperman, B. S.; Lahti, R. Biochemistry 1995, 34, 782-791.

(21) Heikinheimo, P.; Lehtonen, J.; Baykov, A.; Lahti, R.; Cooperman, B. S.; Goldman, A. Structure 1996, 4, 1491-1508.

(22) Samygina, V. R.; Popov, A. N.; Rodina, E. V.; Vorobyeva, N. N.; Lamzin, V. S.; Polyakov, K. M.; Kurilova, S. A.; Nazarova, T. I.; Avaeva, S. M. J. Mol. Biol. 2001, 314, 633-645.

(23) Kankare, J.; Salminen, T.; Lahti, R.; Cooperman, B. S.; Baykov, A. A.; Goldman, A. Biochemistry 1996, 35, 4670-4677.

(24) Pohjanjoki, P.; Lahti, R.; Goldman, A.; Cooperman, B. S. Biochemistry 1998, 37, 1754-1761.

(25) (a) Leopoldini, M.; Russo, N.; Toscano, M. J. Am. Chem. Soc. 2007, 129, 7776-7784. (b) Abashkin, Y. G.; Burt, S. K.; Collins, J. R.; Cachau, R. E.; Russo, N.; Erickson, J. W. In Metal-Ligand Interactions: Structure and Reactivity; Russo, N., Salahub, D. R., Eds.; Nato Science Series; Kluwer: Dordrecht, 1996, Vol. 474; pp 1-22. (c) Olsen, L.; Anthony, J.; Ryde, U.; Adolph, H.-W.; Hemmingsen, L. J. Phys. Chem. B 2003, 107, 2366-2375. (d) Marino, T.; Russo, N.; Toscano, M. J. Am. Chem. Soc. 2005, 127, 4242-4253. (e) Leopoldini, M.; Russo, N.; Toscano, M. J. Phys. Chem. B 2006, 110, 1063-1072.

(26) Lahti, R.; Pohjanoksa, K.; Pitkäranta, T.; Heikinheimo, P.; Salminen, T.; Meyer, P.; Heinonen, J. Biochemistry 1990, 29, 5761-5766.

(27) Avaeva, S.; Ignatov, P.; Kurilova, S.; Nazarova, T.; Rodina, E.; Vorobyeva, N.; Oganessyan, V.; Harutyunyan, E. FEBS Lett. 1996, 399, 99-102.

(28) Tuominen, V.; Heikinheimo, P.; Kajander, T.; Torkkel, T.; Hyytiä, T.; Käpylä, J.; Lahti, R.; Cooperman, B. S.; Goldman, A. J. Mol. Biol. 1998, 284, 1565-1580.
(29) Hyytiä, T.; Halonen, P.; Salminen, A.; Goldman, A.; Lahti, R.; Cooperman, B. S. Biochemistry 2001, 40, 4645-4653.

(30) Kankare, J.; Neal, G. S.; Salminen, T.; Glumhoff, T.; Cooperman, B. S.; Lahti, R.; Goldman, A. Protein Eng. 1994, 7, 823-830.

(31) Gonzalez, M. A.; Webb, M. R.; Welsh, K. M.; Cooperman, B. S. Biochemistry 1984, 23, 797-801.

(32) Harutyunyan, E. H.; Kuranova, I. P.; Vainshtein, B. K.; Höhne, W. E.; Lamzin, V. S.; Dauter, Z.; Teplyakov, A. V.; Wilson, K. S. Eur. J. Biochem. 1996, 239, 220-228.

(33) (a) Becke, A. D. J. Chem. Phys. 1993, 98, 1372-1377. (b) Becke, A. D. J. Chem. Phys. 1993, 98, 5648-5652. (c) Lee, C.; Yang, W.; Parr, R. G. Phys. Rev. B 1988, 37, 785-789.

(34) (a) Himo, F.; Siegbahn, P. E. M. Chem. Rev. 2003, 103, 24212456. (b) Noodleman, L.; Lovell, T.; Han, W.-G.; Li, J.; Himo, F. Chem. Rev. 2004, 104, 459-508. (c) Siegbahn, P. E. M.; Borowski, T. Acc. Chem. Res. 2006, 39, 729-738. (d) Himo, F. Theo. Chem. Acc. 2006, 116, 232240. (e) Ramos, M. J.; Fernandes, P. A. Acc. Chem. Res. 2008, 41, 689698. (f) Chen, S.-L.; Fang, W.-H.; Himo, F. J. Phys. Chem. B 2007, 111, 1253-1255. (g) Chen, S.-L.; Marino, T.; Fang, W.-H.; Russo, N.; Himo, F. J. Phys. Chem. B 2008, 112, 2495-2500. (h) Liao, R.-Z.; Yu, J.-G.; Raushel, F. M.; Himo, F. Chem.-Eur. J. 2008, 14, 4278-4292. (i) Liao, R.-Z.; Yu, J.-G.; Himo, F. Inorg. Chem. 2009, 48, 1442-1448. (j) Chen, S.-L.; Fang, W.-H.; Himo, F. J. Inorg. Biochem. 2009, 103, 274-281.

(35) (a) Barone, V.; Cossi, M. J. Phys. Chem. A 1998, 102, 1995-2001. (b) Cammi, R.; Mennucci, B.; Tomasi, J. J. Phys. Chem. A 1999, 103, 91009108. (c) Klamt, A.; Schüürmann, G. J. Chem. Soc., Perkin. Trans. 2 1993, 799-805. (d) Tomasi, J.; Mennucci, B.; Cammi, R. Chem. Rev. 2005, 105, 2999-3094.

(36) (a) de Meis, L. J. Biol. Chem. 1984, 259, 6090-6097. (b) de Meis, L.; Behrens, M. I.; Petretski, J. H. Biochemistry 1985, 24, 7783-7789. (c) Colvin, M. E.; Evleth, E.; Akacem, Y. J. Am. Chem. Soc. 1995, 117, 43574362.

(37) Frisch, M. J.; Trucks, G. W.; Schlegel, H. B.; Scuseria, G. E.; Robb, M. A.; Cheeseman, J. R.; Montgomery, J. A., Jr.; Vreven, T.; Kudin, K. N.; Burant, J. C.; Millam, J. M.; Iyengar, S. S.; Tomasi, J.; Barone, V.; Mennucci, B.; Cossi, M.; Scalmani, G.; Rega, N.; Petersson, G. A.; Nakatsuji, H.; Hada, M.; Ehara, M.; Toyota, K.; Fukuda, R.; Hasegawa, J.; Ishida, M.; Nakajima, T.; Honda, Y.; Kitao, O.; Nakai, H.; Klene, M.; Li, X.; Knox, J. E.; Hratchian, H. P.; Cross, J. B.; Adamo, C.; Jaramillo, J.; Gomperts, R.; Stratmann, R. E.; Yazyev, O.; Austin, A. J.; Cammi, R.; Pomelli, C.; Ochterski, J. W.; Ayala, P. Y.; Morokuma, K.; Voth, G. A.; Salvador, P.; Dannenberg, J. J.; Zakrzewski, V. G.; Dapprich, S.; Daniels, A. D.; Strain, M. C.; Farkas, O.; Malick, D. K.; Rabuck, A. D.; Raghavachari, K.; Foresman, J. B.; Ortiz, J. V.; Cui, Q.; Baboul, A. G.; Clifford, S.; Cioslowski, J.; Stefanov, B. B.; Liu, G.; Liashenko, A.; Piskorz, P.; Komaromi, I.; Martin, R. L.; Fox, D. J.; Keith, T.; Al-Laham, M. A.; Peng, C. Y.; Nanayakkara, A.; Challacombe, M.; Gill, P. M. W.; Johnson, B.; Chen, W.; Wong, M. W.; Gonzalez, C.; Pople, J. A. Gaussian 03, revision B.04; Gaussian, Inc.: Pittsburgh, PA, 2003.

(38) Zheng, F.; Zhan, C.-G.; Ornstein, R. L. J. Chem. Soc., Perkin Trans. 2001, 2, 2355-2363.

(39) (a) Zhan, C.-G.; Norberto de Souza, O.; Rittenhouse, R.; Ornstein, R. L. J. Am Chem. Soc. 1999, 121, 7279-7282. (b) Koca, J.; Zhan, C.-G.; Rittenhouse, R. C.; Ornstein, R. L. J. Am. Chem. Soc. 2001, 123, 817-826. (c) Zheng, F.; Zhan, C.-G.; Ornstein, R. L. J. Phys. Chem. B 2002, 106, 717-722. (d) Koca, J.; Zhan, C.-G.; Rittenhouse, R. C.; Ornstein, R. L. J. Comput. Chem. 2003, 24, 368-378.

(40) Romero, P. J.; de Meis, L. J. Biol. Chem. 1989, 264, 7869-7873. 